\title{
Harnessing human plasmacytoid dendritic cells as professional APCs
}

\author{
Jurjen Tel • Anne M. van der Leun • \\ Carl G. Figdor · Ruurd Torensma • \\ I. Jolanda M. de Vries
}

Received: 5 December 2011/ Accepted: 19 January 2012/Published online: 1 February 2012

(C) The Author(s) 2012. This article is published with open access at Springerlink.com

\begin{abstract}
The plasmacytoid dendritic cell (pDC) constitutes a unique DC subset that links the innate and adaptive arm of the immune system. Whereas the unique capability of pDCs to produce large amounts of type I IFNs in response to pathogen recognition is generally accepted, their antigen-presenting function is often neglected since most studies on antigen presentation are aimed at other DC subsets. Recently, pDCs were demonstrated capable to present antigen leading to protective tumor immunity. In this review, we discuss how pDCs could be exploited in the fight against cancer by analyzing their capacity to capture, process and (cross-) present antigen.
\end{abstract}

Keywords PIVAC 11 . Plasmacytoid dendritic cells . Antigen-uptake receptors - Antigen presentation . Targeting

This paper is a Focussed Research Review based on a presentation given at the Eleventh International Conference on Progress in Vaccination against Cancer (PIVAC 11), held in Copenhagen, Denmark, October 10-13, 2011. It is part of a CII series of Focussed Research Reviews and meeting report.

J. Tel · A. M. van der Leun - C. G. Figdor - R. Torensma .

I. J. M. de Vries ( $₫)$

Department of Tumor Immunology, Radboud University

Nijmegen Medical Centre and Nijmegen Centre for Molecular

Life Sciences, PO Box 9101, 6500 HB Nijmegen,

The Netherlands

e-mail: J.deVries@ncmls.ru.nl

\section{J. M. de Vries}

Medical Oncology, Radboud University Nijmegen Medical Centre and Nijmegen Centre for Molecular Life Sciences,

Nijmegen, The Netherlands

\section{Introduction}

The human immune system constitutes of a wide variety of cell types to maintain immune homeostasis. In this system, professional antigen-presenting cells (APCs) control the tight balance between tolerance and immunity. All professional APCs exploit an efficient antigen-uptake machinery and long-lived MHC class II-peptide complexes on the cell surface. Dendritic cells (DCs) represent a family of professional APCs that are derived from hematopoietic precursors and have the capacity to induce antigen-specific T-cell responses. Efficient priming is dependent on full maturation of DCs, which is evoked by the recognition of specific pathogen-associated molecular patterns by their distinct pathogen recognition receptors (PPRs). Some of the best characterized PPRs expressed by DCs are the tolllike receptors (TLRs) that are able to bind different pathogen structures like LPS, lipoprotein structures, DNA or single- and double-stranded RNA motifs, thereby initiating a signaling cascade leading to upregulated expression of MHC and co-stimulatory molecules on the DC surface, presentation of antigens and enhanced cytokine production $[1,2]$. After infection or inflammation, this maturation process enables DCs to migrate to the lymph nodes and presents encountered antigens to naïve $T$ cells.

The DC family is very heterogeneous and consists of different DC subsets each with specific functional characteristics. In general, two different DC subtypes can be distinguished, for example, myeloid DCs (mDCs) and plasmacytoid DCs (pDCs). These distinct subsets express various surface receptors and PPRs, which determine their specialized functions (Table 1) [3]. The mDC subset can be identified and subdivided in three different subtypes by the expression of CD11c in combination with their unique surface molecules CD1c (BDCA1), CD141 (BDCA3) and 
Table 1 Phenotypical and functional characteristics of blood DC subsets [3, 6, 45, 62, 82-84]

\begin{tabular}{|c|c|c|c|c|c|c|c|c|c|}
\hline & & \multirow{2}{*}{\multicolumn{2}{|c|}{ pDCs }} & \multicolumn{6}{|l|}{$\mathrm{mDCs}$} \\
\hline & & & & \multicolumn{2}{|l|}{ BDCA-1 } & \multicolumn{2}{|l|}{ BDCA-3 } & \multicolumn{2}{|l|}{ CD16 } \\
\hline & & Steady state & Activated & Steady state & Activated & Steady state & Activated & Steady state & Activated \\
\hline \multirow[t]{9}{*}{ Phenotype } & CD4 & ++ & ++ & + & ++ & + & ++ & + & ++ \\
\hline & CD11c & - & - & +++ & +++ & ++ & +++ & +++ & +++ \\
\hline & CD40 & $+/-$ & +++ & $+/-$ & +++ & $+/-$ & +++ & $+1-$ & +++ \\
\hline & $\mathrm{CD} 80$ & - & ++ & - & ++ & - & ++ & - & ++ \\
\hline & CD83 & - & + & - & + & - & + & - & + \\
\hline & CD86 & + & +++ & + & +++ & + & +++ & ++ & +++ \\
\hline & HLA-DR & ++ & +++ & ++ & +++ & ++ & +++ & ++ & +++ \\
\hline & $\begin{array}{l}\text { HLA- } \\
\text { ABC }\end{array}$ & $+/-$ & ++ & + & ++ & + & ++ & + & ++ \\
\hline & CCR7 & - & ++ & - & ++ & - & ++ & - & ++ \\
\hline \multirow[t]{10}{*}{ Toll-like receptors } & TLR-1 & + & & + & & + & & + & \\
\hline & TLR-2 & - & & ++ & & ++ & & ++ & \\
\hline & TLR-3 & - & & ++ & & ++ & & - & \\
\hline & TLR-4 & - & & + & & + & & + & \\
\hline & TLR-5 & - & & + & & $+1-$ & & + & \\
\hline & TLR-6 & $+/-$ & & + & & + & & + & \\
\hline & TLR-7 & ++ & & $+1-$ & & $+/-$ & & $+/-$ & \\
\hline & TLR-8 & - & & + & & + & & + & \\
\hline & TLR-9 & +++ & & - & & - & & - & \\
\hline & TLR-10 & + & & + & & + & & + & \\
\hline \multirow[t]{4}{*}{ C-type lectin receptors } & DEC-205 & ++ & & ++ & & +++ & & + & \\
\hline & DCIR & + & & + & & - & & + & \\
\hline & BDCA-2 & ++ & & - & & - & & - & \\
\hline & CLEC9a & - & & - & & + & & - & \\
\hline \multirow[t]{6}{*}{ Fc receptors } & $\mathrm{Fc} \alpha \mathrm{R}$ & $+/-$ & & - & & - & & - & \\
\hline & FceRI & + & & + & & - & & - & \\
\hline & $\mathrm{Fc} \gamma \mathrm{RI}$ & - & & - & & - & & + & \\
\hline & Fc $\gamma$ RIIa & + & & + & & + & & + & \\
\hline & $\mathrm{Fc} \gamma \mathrm{RIIb}$ & - & & + & & + & & + & \\
\hline & $\mathrm{Fc} \gamma \mathrm{RIII}$ & - & & + & & - & & $+/-$ & \\
\hline \multicolumn{10}{|l|}{ Upon activation } \\
\hline \multirow[t]{9}{*}{ Cytokine secretion } & $\mathrm{IFN} \alpha$ & +++ & & - & & - & & - & \\
\hline & IFN $\beta$ & +++ & & + & & + & & + & \\
\hline & $\mathrm{IFN} \omega$ & ++ & & - & & - & & - & \\
\hline & IFN $\lambda$ & + & & + & & + & & + & \\
\hline & $\mathrm{IL}-1 \beta$ & + & & + & & + & & + & \\
\hline & IL-6 & ++ & & ++ & & ++ & & +++ & \\
\hline & IL-8 & +++ & & +++ & & +++ & & +++ & \\
\hline & IL-12 & - & & + & & + & & + & \\
\hline & $\mathrm{TNF} \alpha$ & +++ & & +++ & & +++ & & +++ & \\
\hline Migration & & + & & + & & + & & + & \\
\hline \multirow[t]{3}{*}{$\mathrm{Ag}$ (cross-) presentation } & CD4 & + & & + & & + & & + & \\
\hline & Th $1^{\mathrm{a}}$ & + & & + & & + & & + & \\
\hline & CD8 & + & & + & & + & & $+I-$ & \\
\hline
\end{tabular}

a After activation, pDC-derived type I IFNs and mDC-derived IL-12 are involved in the differentiation of Th1 cells 
CD16 [4]. Classically, mDCs reside in peripheral tissues in an immature state and migrate to lymph nodes after their maturation where they produce IL-12 and activate $\mathrm{T}$ cells $[5,6]$. pDCs are an extraordinary subset that differs from the other DC subsets by a specific feature: the capacity to produce large amounts of type I IFNs in response to viral or bacterial stimuli. pDCs employ TLR7 and TLR9, located in intracellular endosomes and lysosomes, to recognize single-stranded viral RNA or unmethylated CpG DNA motifs, respectively [7, 8]. Through the secretion of high levels of type I IFNs, pDCs communicate with other immune cells, for example, they stimulate mDCs to enhance T-cell activation and activate natural killer cells and B cells. In this way, pDCs link the innate and adaptive arm of the immune response [2, 9]. In contrast to $\mathrm{mDCs}, \mathrm{pDCs}$ are hardly found in peripheral tissues under steady-state conditions. Instead, pDCs circulate through the body after entering the bloodstream and reach secondary lymphoid organs via high endothelial venules, while most other DC subsets enter secondary lymphoid organs via the lymph vessels. Following inflammation, pDCs leave the bloodstream and accumulate in the infectious site to take up antigens, followed by migration to lymph nodes to present the encountered antigens [10]. The unique capability of pDCs to produce large amounts of type I IFNs in response to pathogen recognition is well accepted. However, the position of pDCs as professional APCs has long been dictated by the view that $\mathrm{pDCs}$ are inferior to $\mathrm{mDCs}$ as it comes to antigen presentation. In this review, we discuss how pDCs could be exploited in the fight against cancer by analyzing their capacity to capture, process and (cross-) present antigen.

\section{pDCs induce antitumor immune responses leading to protective immunity}

Most DC-based immunotherapy has been performed with monocyte-derived DCs that were generated ex vivo [1113]. Although clinical outcomes were observed in a fraction of patients treated with DCs [12-17], it has been postulated that moDCs might be less effective than naturally occurring DC subsets. pDCs comprise one of these natural DC subsets circulating in the blood and are potential candidates for DC-based antitumor immunotherapy as detailed below.

The observation that human pDCs were able to induce $\mathrm{T}$-cell responses in vitro confirmed results observed in mice where $\mathrm{CpG}$ or influenza virus matured pDCsinduced ovalbumin (OVA)-specific $\mathrm{CD}^{+}{ }^{+}$and $\mathrm{CD}^{+}{ }^{+} \mathrm{T}$-cell responses [18-22]. While CpG-matured pDCs induced $\mathrm{CD}^{+}$T-cell responses against endogenous antigens, no T-cell responses were observed against exogenous OVA antigen [23]. This discrepancy could in part be attributed to the fact that in some studies, pDCs were pulsed with the entire OVA protein, while others used OVA fragments. In other studies with exogenous antigens like influenza A or $\mathrm{HSV}$, pDCs also induced $\mathrm{CD}^{+}{ }^{+}$and $\mathrm{CD} 8^{+}$T-cell responses, again indicating their capacity to present antigens and stimulate T cells [24-26]. Notwithstanding these results, pDCs were less effective in $\mathrm{CD}^{+}{ }^{+}$priming when compared to $\mathrm{mDCs}$ when both are stimulated with TLR agonists, like LPS [19]. This might be explained by the fact that mDCs express high levels of TLR4 where pDCs do not. Salio et al. [23] proposed that high numbers of peptide-pulsed pDCs are equally efficient as peptide-pulsed mDCs in priming of $\mathrm{CD}^{+} \mathrm{T}$ cells. This notion is supported by the finding that murine pDCs exposed to influenza virus induced the generation of memory $\mathrm{CD}^{+} \mathrm{T}$ cells as well as effector $\mathrm{CD}^{+} \mathrm{T}$ cells upon rechallenge with the virus, leading to protective immunity [20]. Further evidence that pDCs can induce protective immunity comes from studies where mice were vaccinated with $\mathrm{CpG}$-matured tumor peptide-pulsed pDCs or pulsed by a Leishmania major ( $L$. major) lysate. Mice vaccinated with tumor peptide-loaded pDCs gained antitumor immunity and were protected upon tumor challenge, whereas nonvaccinated animals showed unhampered tumor growth [23]. This indicates that mature pDCs can effectively generate protective immunity [27]. Together, these data emphasize the potential of pDCs as type I IFN-secreting professional APCs.

\section{Antigen cross-presentation by pDCs}

A potent immune response requires both $\mathrm{CD} 4^{+} \mathrm{T}$-cell and effector $\mathrm{CD}^{+}$responses. To this end, the capacity of DCs to cross-present antigen is absolutely essential. In contrast to the well-defined capacity of human $\mathrm{CD} 141^{+} \mathrm{mDCs}$ and mouse $\mathrm{CD} 8 \alpha^{+}$mDCs to cross-present antigens [28-31], controversy exists about ability of pDCs to cross-present. Although in some studies murine pDCs fail to induce functional $\mathrm{CD}^{+} \mathrm{T}$ cells $[18,32]$, human $\mathrm{pDCs}$ appear to be competent in processing exogenous antigens to be presented in MHC class I molecules [33-35] (Fig. 1). Exogenous antigens captured by pDCs might end up in MHC class I through distinct routes; via an endosome-to-cytosol pathway or via a cytosol-independent pathway [36-38]. Di Pucchio et al. [35] showed that a functional proteasome is not necessary for $\mathrm{pDCs}$ to present captured viral antigens in MHC class I molecules, indicating that pDCs have the capacity to process and load captured antigens directly onto MHC class I molecules in endosomal compartments. This is in contrast with findings showing that exogenous antigens need to be transported from endosomal vesicles into the cytosol, become processed by the proteasome and 
Fig. 1 Plasmacytoid dendritic cells (pDCs) express a wide variety of pattern recognition receptors involved in $\mathrm{pDC}$ function. These receptors can be harnessed to facilitate the targeted delivery of antigen to $\mathrm{pDCs}$, leading to antigen (cross-) presentation and activation of both $\mathrm{CD} 4^{+}$and $\mathrm{CD}^{+}{ }^{+} \mathrm{T}$ cells. Furthermore, receptors that are involved in the recognition of pathogen-associated molecular patterns induce the activation of human pDCs leading to phenotypical maturation as well as the secretion of cytokines and chemokines. Those soluble factors on their turn can attract and induce the activation of other immune cells, thereby enhancing the immune response. The combination of "vaccine targets" for antigen delivery and stimulation largely affects the "immunological output" generated by pDCs

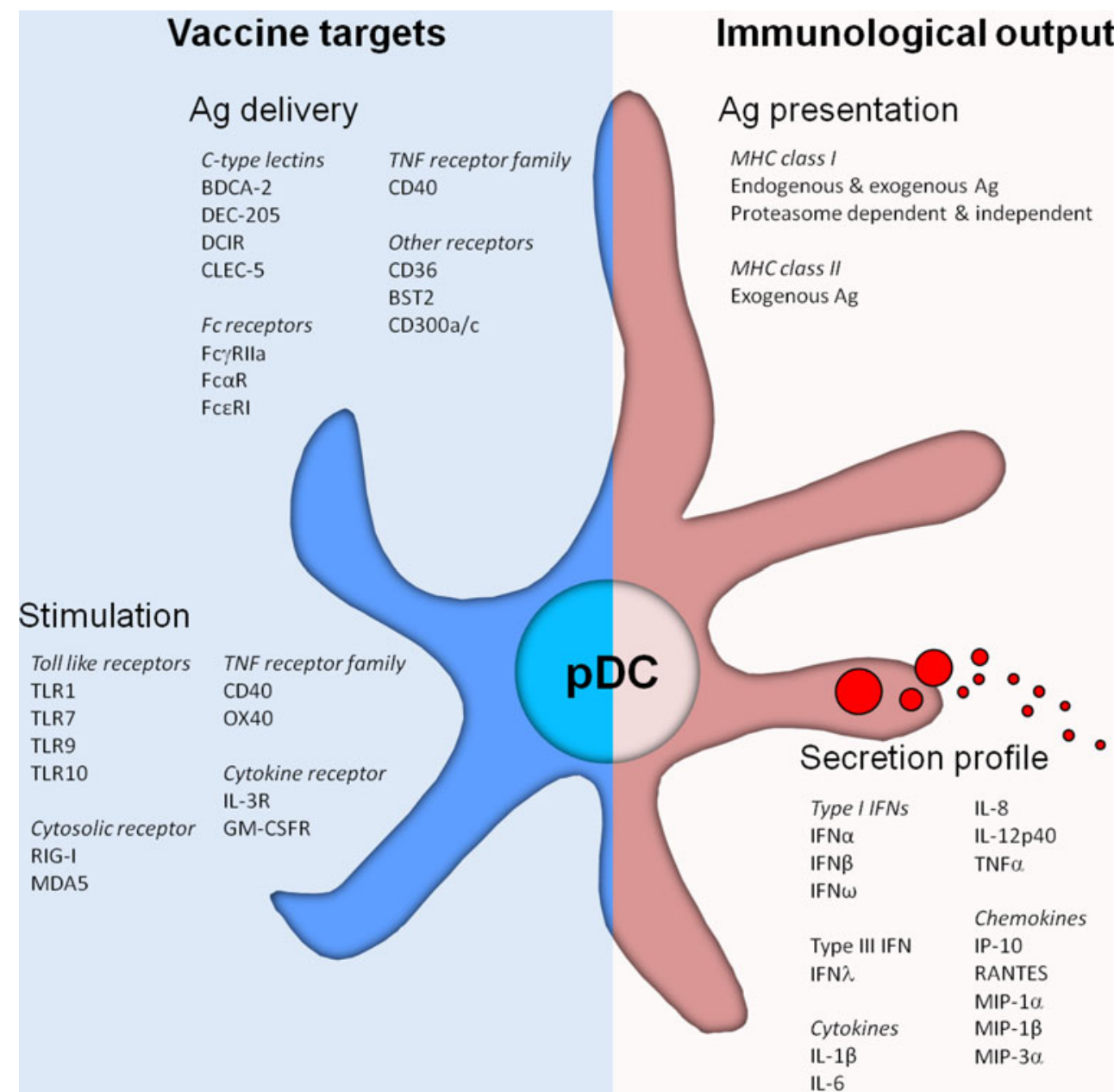

Vaccine targets

Ag delivery

C-typelectin

DCIR

creceptors

FCERI

IL-1ß MIP-30

subsequently loaded on MHC class I molecules, similar to endogenous antigens [39, 40]. Other studies showed that pDCs can cross-present antigens directly after stimulation with viral pathogens with comparable efficacy as $\mathrm{mDC}$ subsets. It has been reported that $\mathrm{pDCs}$ have larger amounts of MHC class I molecules stored in endosomes when compared to other DC subsets and can therefore rapidly transport these MHC class I molecules to the plasma membrane [35]. Taken together, studies performed with human pDCs suggest that an effective cross-presentation machinery is present. Human pDCs can be regarded as professional APCs and should therefore be considered for immunotherapy.

\section{Antigen uptake by pDC}

Two main strategies are exploited in DC-based cancer immunotherapy: (1) isolation and ex vivo stimulation of autologous DCs and (2) via direct targeting of DCs in vivo. Until now, clinical trials have primarily focused on the generation, stimulation and manipulation of DCs ex vivo.
To compose a potent vaccine, the antigenic cargo needs to be efficiently and specifically delivered, avoiding inappropriate release of vaccine content. Furthermore, to explore the most potent mechanism to stimulate immature pDCs with antigens in vivo, it is important to dissect the antigen-uptake and stimulation mechanisms of pDCs. Immature DCs are able to take up various types of exogenous antigens through macropinocytosis, phagocytosis or receptor-mediated endocytosis [41]. Macropinocytosis refers to a process that mediates nonspecific capture of soluble antigens, without the involvement of receptors. While phagocytosis comprises receptor-mediated engulfment of larger antigenic particles or pathogens, receptormediated endocytosis is considered the most specific and efficient mechanism to capture antigens [41].

Phagocytosis and pinocytosis

Like reported for immature $\mathrm{mDCs}$, immature pDCs can phagocytose viral pathogens such as cytomegalovirus, HIV-I and influenza A resulting in priming naïve $\mathrm{CD} 8^{+} \mathrm{T}$ cells $[42,43]$. In contrast to their ability to engulf viruses, 
there has been some controversy whether or not pDCs are involved in the uptake of bacteria. Some studies demonstrate that pDCs were able to take up and get activated by bacteria like S. pyogenes and S. aureus [43, 44], while Piccioli et al. [45] showed that pDCs were not able to phagocytose nor get activated by $\mathrm{S}$. aureus. Other studies demonstrated that pDCs hardly take up apoptotic cells compared with mDCs [46, 47], while Hoeffel et al. [39] showed that pDCs are capable of taking up apoptotic cell fragments. These opposing results suggest that pDCs are endowed with specific PRRs that are involved in the specific recognition of particular bacteria [43]. Other studies have focused on the mechanisms for taking up soluble antigens including $\mathrm{KLH}$ and OVA. Immature pDCs are likely capable of taking up soluble antigens, but less efficient than mDCs $[18,21,48]$. This difference in effectiveness could be caused by the lower macropinocytosis activity of pDCs compared with mDCs [49].

Although pDCs are considered to be ineffective in engulfing particulate antigens like bacteria and apoptotic cells, we previously demonstrated that human pDCs induced immune responses after internalizing particulate matter [50]. Stimulating pDCs with polylactic-co-glycolic acid (PLGA) microparticles packed with antigens and TLR agonists resulted in the activation of antigen-specific $\mathrm{CD}^{+}$ $\mathrm{T}$ cells [50]. Thus, although pDCs are less efficient than $\mathrm{mDCs}$, they can phagocytose and process particles, which simultaneously release TLR agonists and antigens. As a consequence, pDCs mature and MHC class II molecules are loaded with antigens. Interestingly, although human pDCs were found to be less efficient when compared to mDCs in taking up particulate compounds, both cell types were fully matured. These findings suggest that pDCs might even be more competent in handling engulfed materials than mDCs.

\section{Receptor-mediated endocytosis}

Next to the ability to take up encountered pathogens and antigens by phagocytosis, pDCs are also known to express a broad repertoire of antigen-uptake receptors on their cell surface (Table 1; Fig. 1). This large repertoire facilitates the uptake of encountered pathogens and antigens via receptor-mediated endocytosis, resulting in more efficient antigen uptake than via phagocytosis.

\section{Fc receptors}

One of the best defined receptor families relevant for the uptake of microbial pathogens is the Fc receptor family. They mediate endocytosis and presentation of antigens by capturing immune complexes. Fc receptors do not mediate uptake of soluble antigens, but antigens forming immune complexes with antibodies [51, 52]. The human Fc $\gamma \mathrm{R}$ family consists of the activating receptors Fc $\gamma$ RI (CD64), Fc $\gamma$ RIIa/c (CD32a/c) and Fc $\gamma$ RIIIa/b(CD16), and the inhibitory receptor Fc $\gamma$ RIIb (CD32b) [53]. pDCs express Fc $\gamma$ RIIa [54, 55], Fc $\alpha$ R (unpublished observation) and FceRI [56], but not Fc $\gamma$ RI and Fc $\gamma$ RIIIa/b (Table 1). Fc $\gamma$ RIIa-mediated internalization stimulates the redistribution of MHC class II molecules from lysosomal vesicles to the plasma membrane, facilitating presentation of antigen-IgG complexes captured by Fc $\gamma$ RIIa in both MHC class I and MHC class II molecules [54, 57]. The Fc $\gamma$ RIIa surface expression levels are similar for immature and mature pDCs. However, triggering of TLRs results in decreased endocytosis via Fc $\gamma$ RIIa, indicating impaired internalization after pDC maturation. This might prevent the uptake of antigens, which are not associated with TLR activation, to be captured after maturation [55]. Whether $\mathrm{Fc} \alpha \mathrm{R}$ and $\mathrm{Fc} \varepsilon \mathrm{RI}$ expressed by human pDCs are involved in antigen uptake and presentation remains to be established. Triggering FceRI or Fc $\gamma$ RIIa does not affect the expression of surface receptors involved in providing co-stimulatory signals during T-cell activation [54]. However, these receptors differ in their ability to modulate the secretion of type I IFN by pDCs in response to TLR ligation. Although both receptors employ an ITAM for downstream signaling, FceRI triggering strongly impairs TLR9-induced IFN $\alpha$ secretion [56], while Fc $\gamma$ RIIa triggering leaves TLR9induced IFN $\alpha$ secretion unaffected [55].

\section{C-type lectin receptors on $\mathrm{pDCs}$}

Another endocytic receptor family expressed on the immature pDCs are the C-type lectin receptors (CLRs) (Fig. 1). CLRs recognize carbohydrate moieties leading to internalization, the " $\mathrm{C}$ " indicating $\mathrm{Ca}^{2+}$ dependence of carbohydrate binding [58]. BDCA-2 is a type II CLR exclusively expressed by immature pDCs and used as a marker to distinguish immature $\mathrm{pDCs}$ from $\mathrm{mDCs}$ and other immune cells [59]. BDCA-2 is shown to capture antigens decorated with carbohydrates, leading to presentation of the captured antigen on MHC class II molecules. However, triggering BDCA-2 impairs TLR9-mediated type I IFN secretion by $\mathrm{pDCs}$, thereby attenuating the induction of innate immune responses [60]. Furthermore, BDCA-2 expression is reduced by TLR7 and TLR9 signaling, indicating that the endocytic function of BDCA-2 is primarily important in immature pDCs [61]. In addition to BDCA-2, pDCs also express the more broadly expressed CLRs DEC205 and DCIR [62, 63]. Triggering DEC-205 and DCIR both inhibit TLR9-mediated type I IFN secretion by pDCs, but to a lesser extent than triggering through BDCA-2. Moreover, neither DEC-205 nor DCIR affect the expression of co-stimulatory molecules on the plasma membrane 
$[62,64]$. While the expression and/or scavenging function of most endocytic receptors on pDCs, such as DCIR, is downregulated upon TLR-induced activation, DEC-205 expression is enhanced and still able to capture and internalize antigens [62]. Like antigen capture by other CLRs, uptake of antigens by DEC-205 and DCIR leads to antigen processing and presentation in MHC class II molecules, followed by the induction of $\mathrm{CD}^{+} \mathrm{T}$-cell responses [62, 63]. Interestingly, under same conditions targeting of DEC205 on pDCs induced highly similar T-cell responses compared to responses induced by $\mathrm{CD} \mathrm{c}^{+} \mathrm{mDCs}$ and moDCs [62]. These findings reveal that pDCs, although generally considered inferior, are as efficient and professional as other mDCs, generally accepted as professional APC. Whether BDCA-2, DEC-205 and/or DCIR is involved in antigen cross-presentation by human pDCs remains to be elucidated. Initial observations that $\mathrm{mDCs}$ can cross-present antigens captured by DEC-205 and DCIR suggest that both receptors might be able to perform a similar role in pDCs as well [63, 65-67].

\section{Targeted delivery: Which receptor to aim for?}

Facilitating the targeted delivery of particulate vaccines to DCs in vivo via receptor-mediated endocytosis seems an interesting opportunity, since this mechanism allows the specific and simultaneous delivery of maturation factors and antigens. But which receptor should be selected to obtain a potent immune response when considering antigen-presenting pDCs?

Several studies identified receptors for in vivo targeting of pDCs. In mice, Siglec-H and bone marrow stromal cell antigen 2 (BST2) were identified as pDC-specific receptors that opt for interesting targets [68]. Siglec-H is an endocytic receptor and member of the Siglec receptor family. Although most Siglec family members contain an ITIM sequence, Siglec-H lacks this domain [69, 70]. Siglec-H associates with DAP-12, which in spite of having this ITAM motif, result in impaired secretion of type I IFN [71, 72]. In mice, Siglec-H is involved in antigen crosspresentation, as demonstrated by the priming of antigenspecific $\mathrm{CD}^{+} \mathrm{T}$ cells upon antigen uptake via Siglec-H [69]. Recently, Loschko et al. [73] underscored the potency of targeting pDCs in vivo via BST2. In their study, they reported that targeted pDCs were efficient inducers of the expansion of both antigen-specific $\mathrm{CD} 4^{+}$and $\mathrm{CD} 8^{+} \mathrm{T}$-cell responses. Interestingly, they observed protective antitumor responses when targeting pDCs with simultaneous administration of a TLR agonist [73]. This makes Siglec-H and BST2 potent receptors for targeting murine pDCs for the induction of $\mathrm{CD}^{+}$T-cell responses and protective tumor immunity. Although specific for murine pDCs, human pDCs do not express Siglec-H [74]. Freshly isolated as well as activated human pDCs do express BST2 [75]. However, in man expression of BST2 is not restricted to pDCs as it is also expressed by B cells. Moreover, it is upregulated on various cells upon IFN $\alpha$ treatment. Therefore, other receptors expressed by pDCs might be better suited [75]. Regarding the characteristics of the different surface receptors expressed by pDCs, specifically targeting antigen to the ITAM-containing Fc $\gamma$ RIIa seems to be a promising strategy to induce immunity, since Fc $\gamma$ RII is involved in T-cell priming, and moreover triggering Fc $\gamma$ RIIa does not negatively affect type I IFN production. One disadvantage of Fc $\gamma$ RIIa is that it is not uniquely expressed by pDCs, meaning that pDCs cannot be specifically targeted by triggering Fc $\gamma$ RIIa [52]. Similarly, although DEC-205 expression is largely restricted to DCs in mice, it is broadly expressed on different immune cells in man (Table 1) [76]. In this respect, DCIR is expressed by less diverse immune cell types, making this receptor more potent for specific targeting of pDCs. Nevertheless, targeting DCIR might also activate other DC types like mDCs. Combining the stimulation of both DC types unlocks an interesting approach to potentially establish a more potent vaccine, since interaction between pDCs and mDCs has been demonstrated to increase antigen-specific immune responses. Activating pDCs along with mDCs leads also to induction of innate immune responses, likely resulting in an intensified adaptive immune response. pDCs are found to stimulate and enhance the cytokine secretion and cross-presentation of antigens leading to $\mathrm{CD}^{+}{ }^{+} \mathrm{T}$-cell priming by $\mathrm{mDCs}$ and induction of an antiviral immune response by moDCs [77-79]. In turn, pDCs cocultured with mDCs are capable of inducing an immune response against bacteria where they fail to respond on their own [45]. In mice, an enhanced antitumor response was found when mDCs and pDCs were cocultured during pulsing with tumor antigens [80]. Moreover, pDCs were found to crosstalk indirectly with mDCs, via activation of specific lymphocyte subsets that can interact with, and might thereby stimulate, mDCs [81]. Together, these observations strongly suggest that combining pDC activation with the activation of other DC subsets might be advantageous and result in a more powerful immune response. Triggering DCIR could potentially establish such a synergetic immune response, while triggering $\mathrm{pDC}$-specific receptors, like BDCA-2, initiate a more restricted induced immune response. Moreover, triggering DCIR does not completely inhibit TLR-induced type I IFN secretion by $\mathrm{pDC}$ as would be caused by BDCA-2 ligation. We hypothesize that the locally secreted type I IFN is important to establish an effective immune response, since type I IFNs links innate and adaptive immune responses by cross-talk with mDCs, natural killer $\mathrm{T}$ cells, natural killer cells and $\mathrm{B}$ cells. 
Alternatively, targeting CD40 could be considered, since it induces TLR-independent pDC maturation without negatively affecting type I IFN secretion. However, like Fc $\gamma$ RIIa, BST2 and DEC-205, CD40 is expressed on many different cell types other then DCs and might therefore be less powerful for targeting pDCs.

\section{Conclusion}

Human pDCs seem well equipped for therapeutic strategies aimed at eliciting specific immune response and tumor eradication. Although there is still some controversy on the cross-presenting ability of pDCs, several studies demonstrate that they can cross-present antigens and effectively induce antigen-specific $\mathrm{CD}^{+} \mathrm{T}$-cell responses leading to protective tumor immunity in both mice and man. Therefore, it might be interesting to directly target $\mathrm{pDCs}$ in vivo to simultaneously deliver TLR agonists and antigens. Based on existing literature, DCIR seems a potent target, since triggering of this receptor leads to antigen presentation by pDCs as well as other DC subsets without totally blocking the TLR-induced cytokine secretion. Furthermore, combined stimulation of $\mathrm{pDCs}$ and $\mathrm{mDCs}$ seems to induce a more potent and powerful immune response and therefore deserves more elaborate study. This knowledge will certainly help to map the way for DC-based targeting strategies that can be exploited in autoimmune and infectious diseases as well as in cancer.

Acknowledgments This research was supported by NWO Vidi grant 917.76 .363 to $\mathrm{JdV}$, by $\mathrm{EU}$ grants Cancerimmunotherapy (LSHC-CT-2006- 518234) and DC-THERA (LSHB-CT-2004512074), and by the NOTK foundation and the TIL foundation. CF was awarded with a NWO Spinoza prize.

Conflict of interest The authors declare that they have no conflict of interest.

Open Access This article is distributed under the terms of the Creative Commons Attribution License which permits any use, distribution, and reproduction in any medium, provided the original author(s) and the source are credited.

\section{References}

1. Iwasaki A, Medzhitov R (2004) Toll-like receptor control of the adaptive immune responses. Nat Immunol 5(10):987-995

2. Duthie MS, Windish HP, Fox CB, Reed SG (2011) Use of defined TLR ligands as adjuvants within human vaccines. Immunol Rev 239(1):178-196

3. Schreibelt G, Tel J, Sliepen KH, Benitez-Ribas D, Figdor CG, Adema GJ, de Vries IJ (2010) Toll-like receptor expression and function in human dendritic cell subsets: implications for dendritic cell-based anti-cancer immunotherapy. Cancer Immunol Immunother 59(10):1573-1582

4. Mittag D, Proietto AI, Loudovaris T, Mannering SI, Vremec D, Shortman K, Wu L, Harrison LC (2011) Human dendritic cell subsets from spleen and blood are similar in phenotype and function but modified by donor health status. J Immunol 186(11):6207-6217

5. Jarrossay D, Napolitani G, Colonna M, Sallusto F, Lanzavecchia A (2001) Specialization and complementarity in microbial molecule recognition by human myeloid and plasmacytoid dendritic cells. Eur J Immunol 31(11):3388-3393

6. Kadowaki N, Ho S, Antonenko S, Malefyt RW, Kastelein RA, Bazan F, Liu YJ (2001) Subsets of human dendritic cell precursors express different toll-like receptors and respond to different microbial antigens. J Exp Med 194(6):863-869

7. Gilliet M, Cao W, Liu YJ (2008) Plasmacytoid dendritic cells: sensing nucleic acids in viral infection and autoimmune diseases. Nat Rev Immunol 8(8):594-606

8. Krieg AM (2002) CpG motifs in bacterial DNA and their immune effects. Annu Rev Immunol 20:709-760

9. Heil F, Hemmi H, Hochrein H, Ampenberger F, Kirschning C, Akira S, Lipford G, Wagner H, Bauer S (2004) Species-specific recognition of single-stranded RNA via toll-like receptor 7 and 8 . Science 303(5663): 1526-1529

10. Conrad C, Meller S, Gilliet M (2009) Plasmacytoid dendritic cells in the skin: to sense or not to sense nucleic acids. Semin Immunol 21(3):101-109

11. Holtl L, Ramoner R, Zelle-Rieser C, Gander H, Putz T, Papesh C, Nussbaumer W, Falkensammer C, Bartsch G, Thurnher M (2005) Allogeneic dendritic cell vaccination against metastatic renal cell carcinoma with or without cyclophosphamide. Cancer Immunol Immunother 54(7):663-670

12. Jonuleit H, Giesecke-Tuettenberg A, Tuting T, Thurner-Schuler B, Stuge TB, Paragnik L, Kandemir A, Lee PP, Schuler G, Knop J, Enk AH (2001) A comparison of two types of dendritic cell as adjuvants for the induction of melanoma-specific T-cell responses in humans following intranodal injection. Int $\mathrm{J}$ Cancer 93(2):243-251

13. Dhodapkar MV, Steinman RM, Sapp M, Desai H, Fossella C, Krasovsky J, Donahoe SM, Dunbar PR, Cerundolo V, Nixon DF, Bhardwaj N (1999) Rapid generation of broad T-cell immunity in humans after a single injection of mature dendritic cells. J Clin Investig 104(2):173-180

14. Lesterhuis WJ, de Vries IJ, Schreibelt G, Lambeck AJ, Aarntzen EH, Jacobs JF, Scharenborg NM, van de Rakt MW, de Boer AJ, Croockewit S, van Rossum MM, Mus R, Oyen WJ, Boerman OC, Lucas S, Adema GJ, Punt CJ, Figdor CG (2011) Route of administration modulates the induction of dendritic cell vaccineinduced antigen-specific $\mathrm{T}$ cells in advanced melanoma patients. Clin Cancer Res 17(17):5725-5735

15. Banchereau J, Palucka AK, Dhodapkar M, Burkeholder S, Taquet N, Rolland A, Taquet S, Coquery S, Wittkowski KM, Bhardwaj N, Pineiro L, Steinman R, Fay J (2001) Immune and clinical responses in patients with metastatic melanoma to $\mathrm{CD} 34(+)$ progenitorderived dendritic cell vaccine. Cancer Res 61(17):6451-6458

16. De Vries IJ, Krooshoop DJ, Scharenborg NM, Lesterhuis WJ, Diepstra JH, Van Muijen GN, Strijk SP, Ruers TJ, Boerman OC, Oyen WJ, Adema GJ, Punt CJ, Figdor CG (2003) Effective migration of antigen-pulsed dendritic cells to lymph nodes in melanoma patients is determined by their maturation state. Cancer Res 63(1):12-17

17. de Vries IJ, Lesterhuis WJ, Scharenborg NM, Engelen LP, Ruiter DJ, Gerritsen MJ, Croockewit S, Britten CM, Torensma R, Adema GJ, Figdor CG, Punt CJ (2003) Maturation of dendritic cells is a prerequisite for inducing immune responses in advanced melanoma patients. Clin Cancer Res 9(14):5091-5100 
18. Sapoznikov A, Fischer JA, Zaft T, Krauthgamer R, Dzionek A, Jung S (2007) Organ-dependent in vivo priming of naive CD4+, but not CD8+, T cells by plasmacytoid dendritic cells. J Exp Med 204(8):1923-1933

19. Boonstra A, Asselin-Paturel C, Gilliet M, Crain C, Trinchieri G, Liu YJ, O'Garra A (2003) Flexibility of mouse classical and plasmacytoid-derived dendritic cells in directing $\mathrm{T}$ helper type 1 and 2 cell development: dependency on antigen dose and differential toll-like receptor ligation. J Exp Med 197(1):101-109

20. Schlecht G, Garcia S, Escriou N, Freitas AA, Leclerc C, Dadaglio G (2004) Murine plasmacytoid dendritic cells induce effector/ memory CD8+ T-cell responses in vivo after viral stimulation. Blood 104(6):1808-1815

21. Young LJ, Wilson NS, Schnorrer P, Proietto A, ten Broeke T, Matsuki Y, Mount AM, Belz GT, O'Keeffe M, Ohmura-Hoshino M, Ishido S, Stoorvogel W, Heath WR, Shortman K, Villadangos JA (2008) Differential MHC class II synthesis and ubiquitination confers distinct antigen-presenting properties on conventional and plasmacytoid dendritic cells. Nature Immunol 9(11):1244-1252

22. Brimnes MK, Bonifaz L, Steinman RM, Moran TM (2003) Influenza virus-induced dendritic cell maturation is associated with the induction of strong $\mathrm{T}$ cell immunity to a coadministered, normally nonimmunogenic protein. J Exp Med 198(1):133-144

23. Salio M, Palmowski MJ, Atzberger A, Hermans IF, Cerundolo V (2004) CpG-matured murine plasmacytoid dendritic cells are capable of in vivo priming of functional $\mathrm{CD} 8 \mathrm{~T}$ cell responses to endogenous but not exogenous antigens. J Exp Med 199(4):567-579

24. Fonteneau JF, Gilliet M, Larsson M, Dasilva I, Munz C, Liu YJ, Bhardwaj N (2003) Activation of influenza virus-specific CD4+ and CD8+ T cells: a new role for plasmacytoid dendritic cells in adaptive immunity. Blood 101(9):3520-3526

25. Kawamura K, Kadowaki N, Kitawaki T, Uchiyama T (2006) Virus-stimulated plasmacytoid dendritic cells induce CD4+ cytotoxic regulatory T cells. Blood 107(3):1031-1038

26. Cella M, Facchetti F, Lanzavecchia A, Colonna M (2000) Plasmacytoid dendritic cells activated by influenza virus and CD40L drive a potent TH1 polarization. Nature Immunol 1(4):305-310

27. Remer KA, Apetrei C, Schwarz T, Linden C, Moll H (2007) Vaccination with plasmacytoid dendritic cells induces protection against infection with Leishmania major in mice. Eur J Immunol 37(9):2463-2473

28. Jongbloed SL, Kassianos AJ, McDonald KJ, Clark GJ, Ju X, Angel CE, Chen CJ, Dunbar PR, Wadley RB, Jeet V, Vulink AJ, Hart DN, Radford KJ (2010) Human CD141+ (BDCA-3)+ dendritic cells (DCs) represent a unique myeloid DC subset that cross-presents necrotic cell antigens. J Exp Med 207(6): $1247-1260$

29. Bachem A, Guttler S, Hartung E, Ebstein F, Schaefer M, Tannert A, Salama A, Movassaghi K, Opitz C, Mages HW, Henn V, Kloetzel PM, Gurka S, Kroczek RA (2010) Superior antigen cross-presentation and XCR1 expression define human $\mathrm{CD} 11 \mathrm{c}+\mathrm{CD} 141+$ cells as homologues of mouse CD8+ dendritic cells. J Exp Med 207(6):1273-1281

30. Crozat K, Guiton R, Contreras V, Feuillet V, Dutertre CA, Ventre E, Vu Manh TP, Baranek T, Storset AK, Marvel J, Boudinot P, Hosmalin A, Schwartz-Cornil I, Dalod M (2010) The XC chemokine receptor 1 is a conserved selective marker of mammalian cells homologous to mouse CD8alpha+ dendritic cells. J Exp Med 207(6):1283-1292

31. Poulin LF, Salio M, Griessinger E, Anjos-Afonso F, Craciun L, Chen JL, Keller AM, Joffre O, Zelenay S, Nye E, Le Moine A, Faure F, Donckier V, Sancho D, Cerundolo V, Bonnet D, Reis e Sousa C (2010) Characterization of human DNGR1 + BDCA3 + leukocytes as putative equivalents of mouse CD8alpha + dendritic cells. J Exp Med 207(6):1261-1271
32. Jaehn PS, Zaenker KS, Schmitz J, Dzionek A (2008) Functional dichotomy of plasmacytoid dendritic cells: antigen-specific activation of $\mathrm{T}$ cells versus production of type $\mathrm{I}$ interferon. Eur $\mathrm{J}$ Immunol 38(7):1822-1832

33. Belz GT, Shortman K, Bevan MJ, Heath WR (2005) CD8alpha + dendritic cells selectively present MHC class I-restricted noncytolytic viral and intracellular bacterial antigens in vivo. J Immunol 175(1):196-200

34. Lui G, Manches O, Angel J, Molens JP, Chaperot L, Plumas J (2009) Plasmacytoid dendritic cells capture and cross-present viral antigens from influenza-virus exposed cells. PLoS One 4(9):e7111

35. Di Pucchio T, Chatterjee B, Smed-Sorensen A, Clayton S, Palazzo A, Montes M, Xue Y, Mellman I, Banchereau J, Connolly JE (2008) Direct proteasome-independent cross-presentation of viral antigen by plasmacytoid dendritic cells on major histocompatibility complex class I. Nat Immunol 9:551-557

36. Shen L, Rock KL (2006) Priming of T cells by exogenous antigen cross-presented on MHC class I molecules. Curr Opin Immunol 18(1):85-91

37. Cresswell P, Ackerman AL, Giodini A, Peaper DR, Wearsch PA (2005) Mechanisms of MHC class I-restricted antigen processing and cross-presentation. Immunol Rev 207:145-157

38. Rock KL, Shen L (2005) Cross-presentation: underlying mechanisms and role in immune surveillance. Immunol Rev 207:166-183

39. Hoeffel G, Ripoche AC, Matheoud D, Nascimbeni M, Escriou N, Lebon P, Heshmati F, Guillet JG, Gannage M, Caillat-Zucman S, Casartelli N, Schwartz O, De la Salle H, Hanau D, Hosmalin A, Maranon C (2007) Antigen crosspresentation by human plasmacytoid dendritic cells. Immunity 27(3):481-492

40. Colonna M, Cella M (2007) Crosspresentation: plasmacytoid dendritic cells are in the business. Immunity 27(3):419-421

41. Wilson NS, Villadangos JA (2005) Regulation of antigen presentation and cross-presentation in the dendritic cell network: facts, hypothesis, and immunological implications. Adv Immunol 86:241-305

42. Dalod M, Hamilton T, Salomon R, Salazar-Mather TP, Henry SC, Hamilton JD, Biron CA (2003) Dendritic cell responses to early murine cytomegalovirus infection: subset functional specialization and differential regulation by interferon alpha/beta. J Exp Med 197(7):885-898

43. Veckman V, Julkunen I (2008) Streptococcus pyogenes activates human plasmacytoid and myeloid dendritic cells. J Leukoc Biol 83(2):296-304

44. Parcina M, Wendt C, Goetz F, Zawatzky R, Zahringer U, Heeg K, Bekeredjian-Ding I (2008) Staphylococcus aureus-induced plasmacytoid dendritic cell activation is based on an IgG-mediated memory response. J Immunol 181(6):3823-3833

45. Piccioli D, Sammicheli C, Tavarini S, Nuti S, Frigimelica E, Manetti AGO, Nuccitelli A, Aprea S, Valentini S, Borgogni E, Wack A, Valiante NM (2009) Human plasmacytoid dendritic cells are unresponsive to bacterial stimulation and require a novel type of cooperation with myeloid dendritic cells for maturation. Blood 113(18):4232-4239

46. Dalgaard J, Beckstrom KJ, Jahnsen FL, Brinchmann JE (2005) Differential capability for phagocytosis of apoptotic and necrotic leukemia cells by human peripheral blood dendritic cell subsets. J Leukoc Biol 77(5):689-698

47. Stent G, Reece JC, Baylis DC, Ivinson K, Paukovics G, Thomson M, Cameron PU (2002) Heterogeneity of freshly isolated human tonsil dendritic cells demonstrated by intracellular markers, phagocytosis, and membrane dye transfer. Cytometry 48(3): $167-176$

48. de Heer HJ, Hammad H, Soullie T, Hijdra D, Vos N, Willart MA, Hoogsteden HC, Lambrecht BN (2004) Essential role of lung 
plasmacytoid dendritic cells in preventing asthmatic reactions to harmless inhaled antigen. J Exp Med 200(1):89-98

49. Robinson SP, Patterson S, English N, Davies D, Knight SC, Reid CD (1999) Human peripheral blood contains two distinct lineages of dendritic cells. Eur J Immunol 29(9):2769-2778

50. Tel J, Lambeck AJ, Cruz LJ, Tacken PJ, de Vries IJ, Figdor CG (2010) Human plasmacytoid dendritic cells phagocytose, process, and present exogenous particulate antigen. J Immunol 184(8): $4276-4283$

51. Amigorena S, Bonnerot C (1999) Fc receptor signaling and trafficking: a connection for antigen processing. Immunol Rev 172:279-284

52. Fanger NA, Wardwell K, Shen L, Tedder TF, Guyre PM (1996) Type I (CD64) and type II (CD32) Fc gamma receptor-mediated phagocytosis by human blood dendritic cells. J Immunol 157(2):541-548

53. Woof JM, Burton DR (2004) Human antibody-Fc receptor interactions illuminated by crystal structures. Nat Rev Immunol 4(2):89-99

54. Benitez-Ribas D, Adema GJ, Winkels G, Klasen IS, Punt CJ, Figdor CG, de Vries IJ (2006) Plasmacytoid dendritic cells of melanoma patients present exogenous proteins to $\mathrm{CD} 4+\mathrm{T}$ cells after $\mathrm{Fc}$ gamma RII-mediated uptake. J Exp Med 203(7):1629-1635

55. Benitez-Ribas D, Tacken P, Punt CJA, de Vries IJM, Figdor CG (2008) Activation of human plasmacytoid dendritic cells by TLR9 impairs Fc\{gamma\}RII-mediated uptake of immune complexes and presentation by MHC class II. J Immunol 181(8):5219-5224

56. Novak N, Allam JP, Hagemann T, Jenneck C, Laffer S, Valenta R, Kochan J, Bieber T (2004) Characterization of FcepsilonRIbearing CD123 blood dendritic cell antigen-2 plasmacytoid dendritic cells in atopic dermatitis. J Aller Clin Immunol 114(2): 364-370

57. Regnault A, Lankar D, Lacabanne V, Rodriguez A, Thery C, Rescigno M, Saito T, Verbeek S, Bonnerot C, Ricciardi-Castagnoli P, Amigorena S (1999) Fcgamma receptor-mediated induction of dendritic cell maturation and major histocompatibility complex class I-restricted antigen presentation after immune complex internalization. J Exp Med 189(2):371-380

58. Figdor CG, van Kooyk Y, Adema GJ (2002) C-type lectin receptors on dendritic cells and langerhans cells. Nat Rev Immunol 2(2):77-84

59. Dzionek A, Inagaki Y, Okawa K, Nagafune J, Rock J, Sohma Y, Winkels G, Zysk M, Yamaguchi Y, Schmitz J (2002) Plasmacytoid dendritic cells: from specific surface markers to specific cellular functions. Human Immunol 63(12):1133-1148

60. Cao W, Zhang L, Rosen DB, Bover L, Watanabe G, Bao M, Lanier LL, Liu YJ (2007) BDCA2/Fc epsilon RI gamma complex signals through a novel BCR-like pathway in human plasmacytoid dendritic cells. PLoS Biol 5(10):e248

61. Wu P, Wu J, Liu S, Han X, Lu J, Shi Y, Wang J, Lu L, Cao X (2008) TLR9/TLR7-triggered downregulation of BDCA2 expression on human plasmacytoid dendritic cells from healthy individuals and lupus patients. Clin Immunol 129(1):40-48

62. Tel J, Benitez-Ribas D, Hoosemans S, Cambi A, Adema GJ, Figdor CG, Tacken PJ, de Vries IJ (2011) DEC-205 mediates antigen uptake and presentation by both resting and activated human plasmacytoid dendritic cells. Eur J Immunol 41(4):1014-1023

63. Meyer-Wentrup F, Benitez-Ribas D, Tacken PJ, Punt CJA, Figdor CG, de Vries IJM, Adema GJ (2008) Targeting DCIR on human plasmacytoid dendritic cells results in antigen presentation and inhibits IFN-\{alpha\} production. Blood 111(8):4245-4253

64. Meyer-Wentrup F, Cambi A, Joosten B, Looman MW, de Vries IJM, Figdor CG, Adema GJ (2009) DCIR is endocytosed into human dendritic cells and inhibits TLR8-mediated cytokine production. J Leukoc Biol 85(3):518-525
65. Bonifaz L, Bonnyay D, Mahnke K, Rivera M, Nussenzweig MC, Steinman RM (2002) Efficient targeting of protein antigen to the dendritic cell receptor DEC-205 in the steady state leads to antigen presentation on major histocompatibility complex class I products and peripheral $\mathrm{CD} 8+\mathrm{T}$ cell tolerance. $\mathrm{J}$ Exp Med 196(12):1627-1638

66. Geijtenbeek TBH, Gringhuis SI (2009) Signalling through C-type lectin receptors: shaping immune responses. Nat Rev Immunol 9(7):465-479

67. Klechevsky E, Flamar AL, Cao Y, Blanck JP, Liu M, O’Bar A, Agouna-Deciat O, Klucar P, Thompson-Snipes L, Zurawski S, Reiter Y, Palucka AK, Zurawski G, Banchereau J (2010) Crosspriming $\mathrm{CD} 8+\mathrm{T}$ cells by targeting antigens to human dendritic cells through DCIR. Blood 116 (10):1685-1697

68. Blasius AL, Giurisato E, Cella M, Schreiber RD, Shaw AS, Colonna M (2006) Bone marrow stromal cell antigen 2 is a specific marker of type I IFN-producing cells in the naive mouse, but a promiscuous cell surface antigen following IFN stimulation. J Immunol 177(5):3260-3265

69. Zhang J, Raper A, Sugita N, Hingorani R, Salio M, Palmowski MJ, Cerundolo V, Crocker PR (2006) Characterization of Siglec-H as a novel endocytic receptor expressed on murine plasmacytoid dendritic cell precursors. Blood 107(9):36003608

70. Crocker PR (2005) Siglecs in innate immunity. Curr Opin Pharmacol 5(4):431-437

71. Blasius AL, Cella M, Maldonado J, Takai T, Colonna M (2006) Siglec-H is an IPC-specific receptor that modulates type I IFN secretion through DAP12. Blood 107(6):2474-2476

72. Blasius AL, Colonna M (2006) Sampling and signaling in plasmacytoid dendritic cells: the potential roles of Siglec-H. Trend Immunol 27(6):255-260

73. Loschko J, Schlitzer A, Dudziak D, Drexler I, Sandholzer N, Bourquin C, Reindl W, Krug AB (2011) Antigen delivery to plasmacytoid dendritic cells via BST2 induces protective T cellmediated immunity. J Immunol 186(12):6718-6725

74. Fitzgerald-Bocarsly P, Jacobs ES (2010) Plasmacytoid dendritic cells in HIV infection: striking a delicate balance. J Leukoc Biol 87(4):609-620

75. Cao W, Bover L, Cho M, Wen X, Hanabuchi S, Bao M, Rosen DB, Wang YH, Shaw JL, Du Q, Li C, Arai N, Yao Z, Lanier LL, Liu YJ (2009) Regulation of TLR7/9 responses in plasmacytoid dendritic cells by BST2 and ILT7 receptor interaction. J Exp Med 206(7):1603-1614

76. Kato M, McDonald KJ, Khan S, Ross IL, Vuckovic S, Chen K, Munster D, Macdonald KP, Hart D (2006) Expression of human DEC-205 (CD205) multilectin receptor on leukocytes. Int Immunol 18(6):857-869

77. Kuwajima S, Sato T, Ishida K, Tada H, Tezuka H, Ohteki T (2006) Interleukin 15-dependent crosstalk between conventional and plasmacytoid dendritic cells is essential for CpG-induced immune activation. Nat Immunol 7(7):740-746

78. Nierkens S, den Brok MH, Garcia Z, Togher S, Wagenaars J, Wassink M, Boon L, Ruers TJ, Figdor CG, Schoenberger SP, Adema GJ, Janssen EM (2011) Immune adjuvant efficacy of CpG oligonucleotide in cancer treatment is founded specifically upon TLR9 function in plasmacytoid dendritic cells. Cancer Res 71(20):6428-6437

79. Kramer M, Schulte BM, Eleveld-Trancikova D, van Hout-Kuijer M, Toonen LWJ, Tel J, de Vries IJM, van Kuppeveld FJM, Jansen BJH, Adema GJ (2010) Cross-talk between human dendritic cell subsets influences expression of RNA sensors and inhibits picornavirus infection. J Innate Immun 2(4): 360-370

80. Lou Y, Liu C, Kim GJ, Liu YJ, Hwu P, Wang G (2007) Plasmacytoid dendritic cells synergize with myeloid dendritic cells in 
the induction of antigen-specific antitumor immune responses. J Immunol 178(3):1534-1541

81. Montoya CJ, Jie HB, Al-Harthi L, Mulder C, Patino PJ, Rugeles MT, Krieg AM, Landay AL, Wilson SB (2006) Activation of plasmacytoid dendritic cells with TLR9 agonists initiates invariant NKT cell-mediated cross-talk with myeloid dendritic cells. J Immunol 177(2):1028-1039

82. Schreibelt G, Klinkenberg LJ, Cruz LJ, Tacken PJ, Tel J, Kreutz M, Adema GJ, Brown GD, Figdor CG, de Vries IJM (2012) The $\mathrm{C}$ type lectin receptor CLEC9A mediates antigen uptake and (cross-)presentation by human blood BDCA3+ myeloid dendritic cells. Blood. doi:10.1182/blood-2011-08-373944

83. MacDonald KP, Munster DJ, Clark GJ, Dzionek A, Schmitz J, Hart DN (2002) Characterization of human blood dendritic cell subsets. Blood 100(13):4512-4520

84. Piccioli D, Tavarini S, Borgogni E, Steri V, Nuti S, Sammicheli C, Bardelli M, Montagna D, Locatelli F, Wack A (2007) Functional specialization of human circulating CD16 and CD1c myeloid dendritic-cell subsets. Blood 109(12):5371-5379 